\title{
GOVERNING THE GLOBAL LAND GRAB: MULTIPOLARITY, IDEAS AND COMPLEXITY IN TRANSNATIONAL GOVERNANCE
}

\author{
Matias E. Margulis* \\ Division of History and Politics \\ University of Stirling \\ Email:m.e.margulis@stir.ac.uk \\ Tony Porter \\ Department of Political Science \\ McMaster University
}

\begin{abstract}
Since 2008, a series of new regulatory initiatives have emerged to address large-scale land grabs. These initiatives are occurring simultaneously at multiple levels of social organization instead of a single, overarching institutional site. A significant portion of this activity is taking place at the transnational level. We suggest that transnational land governance is indicative of emerging shifts in the practice of governance of global affairs. We analyze such shifts by asking two related questions: what does land grabbing tell us about developments in transnational governance, particularly with regard to North-South relations, and what do these developments in transnational governance mean for regulating land grabbing?
\end{abstract}

Keywords: Global governance, land grabbing, multipolarity, agricultural investment, risk, complexity, social protection

*This is an Accepted Manuscript of an article published in Globalizations 10(1): 65-86 (2013), available at: http://www.tandfonline.com/doi/full/10.1080/14747731.2013.760930 


\section{Introduction}

Since 2008, a series of new regulatory initiatives and global institution-building projects have emerged to address large-scale land grabs. These are occurring simultaneously at multiple levels of social organization instead of a single, overarching institutional site. The range of actors operating in this web is considerable and highly diverse and we see states, multilateral organizations, global civil society, corporate actors, and peasant farmers engaging in and demanding diverse modes of governance. Taken together, these signal the emergence of what might be termed transnational land governance.

We develop four propositions about the complexity of transnational land governance that, in our view, have not been accorded sufficient attention in the literature on land grabbing and permits for a more critical study of land grabbing and global governance. The first proposition is that the institutional arrangements associated with US dominance and the earlier colonial period of land grabbing are being replaced by more complex, polycentric ones operating in an increasingly multipolar global political economy, rendering the previous North-South and WestEast cleavages less relevant. The second proposition is that the ideational and the material aspects of transnational governance are becoming more directly entangled and complex as we approach or surpass the Earth's physical ability to sustain our civilization and a multiplicity of actors mobilize normative beliefs and scientific knowledge to address intensified resource challenges and land conflicts. The third proposition is that conflict and collaboration among states and other actors will play out through the informal complex of transnational land governance arrangements rather than undermining or replacing them, for instance by developing purely local or more formal, legalized international solutions. The fourth proposition is that the best chance for protecting vulnerable populations, often subject to illegal and violent dispossession of their land, is for concerned transnational advocacy networks and states to work through and seek to orchestrate the informal complex of transnational land governance towards social justice ends. The next section of the essay develops the theoretical aspects of the above questions. The following sections then examine the relevance of our propositions to land grabbing.

\section{Theorizing New Developments in Transnational Governance}

There is a widespread sense that the pace of change in global affairs is accelerating, perhaps even catastrophically. Scholars have made important advances in understanding the significance of these changes, moving us well beyond older models of international affairs such as state-centric realism. It is important to build on these insights from studies of global and transnational governance to know how best to regulate or challenge land grabbing. In this section, we draw on insights from existing studies to develop our four propositions.

\section{Beyond Older Colonial and Unipolar Power Relations}

The global financial and economic crisis that began in 2007 revealed most clearly significant shifts in the balance of power among key international actors. The replacement of the Group of Eight (G8) by the Group of Twenty (G20) at the Heads of State level and the incorporation of the G20's developing country members into all the significant institutions in the international financial architecture marked decisively the arrival of new participants at the table of great 
powers. This was reinforced by the damage the crisis did to the US and European economies and to the credibility of their economic models, and the strength displayed by other economies, such as China's or Brazil's. These shifts in the balance of power are not confined to global finance but demonstrable across diverse governance fields, including international trade (Narlikar and Tussie, 2004; Narlikar and Wilkinson 2004), climate change (Hochstetler and Viola, 2012; Vihma, 2011; Barros-Platiau 2010; Williams, 2005), money (Bowles and Wang, 2010), energy (Victor and Yeuh, 2010; Lesage, Van de Graaf and Westphal, 2010) and oceans (Suárez de Vivero and Rodríguez Mateos, 2010). Exceptions remain, such as emerging powers limited inroads at the IMF and World Bank evident in these countries' voting shares (Wade, 2011). However the power shift is evident even within these institutions, as the increased prominence of emerging powers in foreign aid is changing the theory and practice of global development and no longer the exclusive remit of the North (see de Haan, 2011; Walz and Ramachadran, 2011; TanMullins, Mohan and Power, 2010; Dauvergne and Farias, 2012). This change has been called a 'silent revolution' in global development (Woods, 2008).

Our point is not to claim that the US has been dislodged from its privileged position. Clearly, the US remains a dominant actor. Nevertheless the US is experiencing a relative erosion of power, introducing new dynamics to the global system and making possible future trajectories in transnational governance that may not have been imaginable previously. Consequently, talk of US empire or unipolarity, which had been fashionable earlier in the decade, is less useful today to the extent it renders invisible, or implicitly makes secondary, the power dynamics of multipolarity.

Two lessons from international relations theory for understanding mulitpolarity are clear. The first is that governance is likely to be more complicated with larger numbers of major players at the table with ever more diverse interests (see Lake, 1993). A second, discussed further below, is that polarity is only one among many factors that shape transnational governance, and other forms of power and order than the conventional state capabilities that theories of polarity focus on are also important. These changes are highly relevant to land grabbing, and lead to our first proposition: the political and economic institutions associated with colonialism and US unipolarity are being supplanted by a more complex set of relationships, in which old cleavages that separated North and South or a capitalist West and a state-centric East are no longer as relevant.

\section{The Ideational, the Material, and the Earth's Limits}

Two quite different aspects of transnational governance have displayed increased prominence in recent years: its ideational and material aspects. Inspired by the 'cultural turn' in the social sciences, the increased importance of the ideational aspect is evident in a long list of theoretical innovations in study of international relations and global governance, including epistemic communities (Haas, 1999), soft power (Nye, 2005), constructivism (Wendt, 1995), poststructuralism (de Goede, 2006), cultural political economy (Jessop, 2004), and legitimacy (Zürn, 2004; Cashore, 2003). The increased complexity of materiality in transnational governance is evident in the major concerns that have assumed a higher priority in global public policy, including sustainable development and climate change, which reference the material limits of the Earth; global health issues which concern the materiality of the body; and global poverty alleviation, which involves material standards of living. 
While initially much of the focus of ideational research programs within international relations was on whether ideas could shape the interactions among states, it is increasingly urgent today to understand better the more direct power relationships between transnational ideas and the materiality of the Earth and its life-forms. The mediating role of states in this relationship can still be important. However many of these material/ideational interactions do not run through states, for instance when new private sector ideas like genetic engineering have direct material effects on the Earth and its life-forms. Risk has become increasingly important in managing the interactions between humans and our environment, including in specific interactions that are some distance from traditional centralized state policies (Aradau and Van Munster, 2007; Power, 2007).

This leads to our second proposition: normative beliefs and scientific knowledge are important not only because they influence states, but also because they directly interact with the intensified resource challenges and land conflicts that accompany the Earth's diminishing physical ability to sustain our civilization.

\section{The Complexity of Transnational Governance}

There has been a great deal of scholarly work done to illuminate the complexity of transnational governance. ${ }^{1}$ State principals delegate to non-state agents or intergovernmental organizations that they do not fully control. Business and other non-state actors produce and implement rules and operations that states would have provided in previous times. One theme in this literature is that the local, national and global interact in complex ways.

An emerging theme in this literature is that it is important to analyze both the autonomy of particular regimes or clusters of institutions and their interactions with one another. This contrasts, for instance, with an earlier research program on international regimes that focused on one regime at a time and sought to analyze its relationship with the states involved in it (Krasner, 1982). A growing number of studies have shown that interaction among regimes and/or clusters of institutions is deepening and producing uncertainty for actors (Raustialia and Victor, 2004). Heightened uncertainty may lead to new cooperation and coordination problems, such as constraining or chilling effects by one institution on another (Conca, 2000; Eckersley, 2004; Axelrod 2011 in Oberthur and Stokke; Veggeland and Borgen, 2005; Oberthür and Gehring, 2006) or 'spillovers' effects that can reinforce fragmentation and regime integration/ separation dynamics (Biermann et al., 2009; Johnson and Urpelainen, 2012). Uncertainty also creates opportunities for policy entrepreneurs and new ideas to enter global policy spaces that may set governance along new pathways.

Alter and Meunier (2009) for instance identify the systemic effects of complexity, such as an increase in chessboard politics where states manipulate complexity, for instance through forum shifting, but they also create relatively autonomous small group environments because states engage in a series of smaller forums instead of a few large universal intergovernmental organizations. Abbott and Snidal (2009) treat this as a shift from old governance, which is top down, to transnational new governance in which states orchestrate a variety of institutions that may be formal or informal, public or private. Jessop and Sum (2006: 267) call this metagovernance (setting the rules for other governance bodies) and collibration (working to modify the balance of power among them). This is similar as well to the use by Braithwaite and Drahos (2000) of the concept of enrolment from actor-network theory, where even weaker actors can enhance their power by creating programs that attract adherence from decentralized networks 
that they do not definitively control. "Orchestration”, “collibration”, and “enrolment” are similar concepts in their emphasis on the importance for successful outcomes of strategic engagement with a loosely defined set of relatively autonomous zones of governance, rather than reliance on rules emanating from a single center of control. However "enrolment" is best suited to the identification of opportunities for weak or non-state actors to initiate and benefit from such engagement. $^{2}$

This leads to our third proposition: the types of informal mediating governance institutions that have proliferated will continue to grow, and the altered balance of power will play out through them, rather than undermining them. This development is particularly salient for understanding emergent transnational land governance because we suggest that new regulatory initiatives are likely to interact and overlap with a wider constellation of regimes and clusters of institutions. Those actors that do not recognize the significance of these interactions are likely not to respond effectively to the governance opportunities and challenges that accompany them.

\section{Strategies for Protecting the Vulnerable}

Our analysis leads us to formulate a fourth and more practical proposition: that smaller and poorer actors will be most successful in achieving social justice-oriented goals, including the revalorization of collective/communal land rights and small-scale agriculture, by working through these types of complex transnational governance rather than trying to avoid or reverse them, for instance by focusing more exclusively on solutions at the local level or at the formal intergovernmental level (for instance through treaties). This view is consistent with research by Braithwaite and Drahos (2000), who have proposed a number of ways that weaker actors can prevail over stronger actors in transnational governance by making use of its complex and normative character, successfully enrolling other actors and networks. Such strategies have worked in various governance fields. Take, for instance, transnational advocacy for human rights (Keck and Sikking, 1998), access to medicines (Sell and Prakash, 2004), and digital copyright (Dobusch and Quack, 2012). Our view is also consistent with research on the experience of developing countries in transnational networks by Martinez-Diaz and Woods (2009). Therefore, a transnational governance framework is useful to the extent that it can demonstrate how weak and strong actors can use formal and informal enrolment strategies to influence decision-making at multiple-scales. It is also important to understand dynamics that lead to the 'disenfranchisement' (Fisher and Green, 2006) of weaker actors in transnational governance in order to develop strategies to prevent this. These approaches challenges more state-centric and rationalist views that would see these complex and fragile networks being undermined by interstate conflict, by a decline in the support provided them by US hegemony, ideology, or business, or by a resurgence of territorially-based nationalism or regionalism. It also challenges Drezner's (2009, p. 66) more pessimistic view that sees the undermining of formal legal obligations that the growth of these informal institutions represent as beneficial to powerful states.

\section{Land Grabbing, North-South Relations, and Complexity in Transnational Governance}

We now begin to assess the relevance of these propositions for the issue of land grabbing. Land grabbing has generated a global debate over whether such large-scale investment in agriculture 
can promote pro-poor economic growth and sustainable development or whether instead it will exacerbate food insecurity, ecological deterioration and political instability in developing countries (Cotula et al, 2009; HLPE, 2011). Scholarship has primarily focused on the local and national case studies where land grabbing is occurring and how is being resisted. Links to globallevel processes, such as the interplay with the political economy of biofuels, land reform, and agricultural restructuring in developing countries (Borras, McMichael and Scoones, 2010; Zoomers, 2010) are becoming better understood.

Like the other contributors to this volume, our view is that we need to pay more attention to the transnational dimensions of land grabbing and its governance. The proliferating literature on land grabbing is providing us a clearer view of its scale, location and characteristics albeit with big gaps in knowledge related to the lack of transparency and public disclosure of most transactions. ${ }^{3}$ Rather than reproduce those overviews here, we proceed directly to our analysis of the three new developments in transnational governance that we discussed above.

\section{Beyond Older Colonial and Hegemonic Power Relations}

We suggest the utility of comparing the balance of state power across historical periods to highlight the political and economics institutions associated with land grabbing and how such institutions have shaped North-South relations. For our purposes, it is important to recognize that the current land grab is a massive and growing trend (World, Bank 2009; Anseeuw et al, 2011; Oxfam, 2012). ${ }^{4}$ However, this section will show that despite some similarities with earlier periods, current global power relations differ significantly from earlier ones.

In the era of colonialism, European sovereign states - Spain, the Netherlands, France and Great Britain - were the drivers of the land grab in the pursuit of expanding their national wealth and empires. During this period core-periphery relations dominated with imperial powers administering social, economic and political exchanges within the colonial territories. Coreperiphery exchanges facilitated the transfer of wealth from colonies to serve the interests of an imperial power (Wallerstein, 1974; Hobsbawn, 1987).

After World War II the role of land in the developing world began to change. Formal colonialism began to disappear and US hegemony became a dominant feature of the global political economy (Ruggie, 1982). The US and its allies were not primarily concerned with the direct acquisition of land in the Global South. An important exception is the ownership of plantations such as those of the United Fruit Company, including the notorious case of CIA involvement in the 1954 overthrow of the Guatemalan government when it threatened that firm's interests in that country (Immerman, 1983). However, the general trend during this period was towards nationally-oriented agricultural production, which, with the input of imported fertilizer and mechanization technology and the orientation to mass national markets corresponded to the form of production that has been labeled Fordism (Busch and Bain, 2009; McMichael, 2009). Multinational corporations like Cargill and Monsanto dominated agrifood processing and trade that resulted but did not focus on direct foreign investment in land. In the socialist East and in many developing countries the state would often claim ownership of part or all of the farmland. Global institutions relevant to agriculture, such as the food aid regime that assisted in the disposal of Northern agricultural surpluses, or the exclusion of agriculture from the General Agreement on Tariffs and Trade (GATT), reflected these overall aspects of the post-World War II political economy of agriculture, and the pre-eminent role of the US in organizing it (Friedmann, 1992). 
Present land grabs are characterized by complex and polycentric relationships that do not easily fit a core-periphery framework. Certainly many land grabs do have some characteristics of core-periphery relations. For example, Chinese land acquisitions in rural Africa suggest significant asymmetries of power and patterns of exploitation very closely resembling coreperiphery relations associated with the era of imperialism given China's recent ascendency in global affairs (see Ayers, 2012). However these do not come with formal colonial control, and elsewhere the situation is even more complex. For instance, substantial Chinese land acquisitions in rural Australia are not captured well by a core-periphery label. Brazilian investors are major players in the purchase of farmland across South America (Borras et al, 2011, p. 24; Dauvergne and Neville, 2010) and increasingly in Africa, which is a major target of Brazilian foreign and commercial policy (White 2010). This policy of outward investment has strong and active support from the Brazilian state because it is increasing its firms profile in the agrifood sector, in which it is a global leader. Yet Brazilian land is also a target of foreign commercial interests and investment, which has prompted the Brazilian Congress to reform land ownership laws in order to curb speculative foreign investment (on 'land grabbed land grabbers' see Borras, Franco and Wang, 2013, this volume; Perrone, 2013, this volume).

During the colonial era land was most often acquired by direct violent means and its legal ownership held by the titled monarchs of Europe in perpetuity (and later in common public trusts during the emergence of modern nation-states in the former colonies). Contemporary land grabs involve negotiated transfer of legal property rights between government or traditional land owners to investors. We recognize that the legitimacy and legality of many transactions remain deeply contested, that sporadic violence continues to occur and that land grabbing has increased the insecurity of many communities. Nevertheless, current land grabs are primarily mediated through formal practices (e.g., contracts, memorandum of understanding) sanctioned by the governance practices of national and subnational authorities and by transnational economic actors that have legal personality (Alden Wily 2012).

The political economy of land in the earlier period of US hegemony differs in four additional ways from contemporary land acquisitions. First, the sources of capital for foreign direct investment in the food-feed-fuel complex are more varied then before, including private investors that have not otherwise specialized in agriculture and sovereign wealth funds or stateowned enterprises from emerging developing countries. Second, current land grabs are taking place in the context of a broader shifts in the agrifood industry where deregulated global trade, financialization, and advances in biotechnology and production methods are rapidly reorganizing the sector, precipitating a decline of the relative power of traditional agrifood corporations such as Cargill in favour of retailers such as Walmart and agrifood transnationals from the Global South (e.g., Brazil's JBS now boasts the status as the world largest producer of beef) (Clapp and Fuchs, 2009; Hopewell 2012; McMichael 2012). Third, there is an upswing in interest in direct foreign investment in land as a new asset class, notably by new actors such as private and public (i.e., national) pension funds estimated to be over \$US 5 billion (GRAIN, 2011: 2012). Such investment in land relates to its speculative value and the hopes of mitigating risk through its 'safe haven' status (Savills, 2012) and hopes for new sources of profit from biofuels, new agricultural technologies, or higher quality branded produce and processed food for which its origins and the conditions of its production matter. Fourth, developing countries are actively courting and facilitating direct foreign investments after decades of public disinvestment in agriculture, reflecting the reorientation of national policy towards a greater emphasis on the agricultural sector (see Borras et al forthcoming) . This practice is supported by changes in the 
global policy and governance terrain such as the new global development paradigm of agricultural investment-led poverty reduction that has emerged as a major component of the G8/G20's response to the 2008 global food crisis, such as the L'Aquila Food Security Initiative and the Alliance for Food Security and Nutrition and World Bank's global food security fund (Margulis, 2012).

Overall then our proposition fits well with contemporary land grabbing. More complex sets of relationships are replacing older power relationships between North and South or between a US-led capitalist West and state-centric regions elsewhere.

\section{The Ideational, the Material, and the Earth's Limits}

There are numerous ways that land grabbing is related to a new and significant presence of material systemic threats to the Earth and its life-forms (see Foley et al., 2005). The search for land is driven to a significant degree by concerns that the Earth's cultivable land is running out (Bringenzu et al 2012; Lambin and Meyfroidt, 2011; Harvey and Pilgrim, 2011). The same applies to its usable water (Mehta, Veldwisch, and Franco, 2012; Smaller and Mann, 2009; Barlow, 2007). In part this is evident in the prominence in land grabbing of those countries where land is already scarce or highly degraded, who fear for their own food security, such as the Gulf states (Woertz, 2013, this volume). It is also evident in the anticipation of investors with long time horizons (such as sovereign wealth funds that run on commercial principles) that land prices are going to rise as scarcity increases. ${ }^{5}$ Climate change, which may seriously damage the productivity of existing agricultural land, exacerbates the risks associated with shortages of land. The proliferation of 'green grabs' are important here as actors invest in land in hopes of slowing and/or repairing ecological damage but also in creating global markets for the selling and trading of 'ecosystem services' (Fairhead, Leach and Scoones, 2012). The prominent place of biofuels as a driver of land grabbing reflects the exhaustion of another of the Earth's resources: fossil fuels (see, e.g., Borras, McMichael and Scoones, 2010). This is now an integrated global threat, tied together by prices in global markets, and by the use of agriculture to produce energy, which is as central to our industrial civilization as food. Struggles likely will intensify between countries with dwindling resources and countries with the remaining stocks.

The materiality of resource scarcities does not make them self-evident. On the contrary, both the problem and its solution have crucial contested ideational dimensions that involve far more complexity than a more traditional supply of ideas to policymakers by lobbyists or experts. For example, the impact of biofuel production on land in Africa can be influenced simultaneously by European voter preferences on legislation requiring the use of biofuels in vehicles, the calculations of scientists who are assessing the climate change problem and the viability of biofuel technologies, the expectations of transnational investors investing in a particular plot of land, and the knowledge involved in practical implementation challenges for small farmer or agricultural workers growing a new biofuel crop such as jatropha (see, e.g., Hunsberger, 2010). This complexity provides a great many locations at which the system driving land grabbing can and must be challenged if it is to be altered. In contrast to earlier models of international politics where it was easier to address international problems by influencing decisionmakers in a few powerful states, or by altering the text of a key treaty, today large expanses of the transnational flows of power and knowledge that shape the material practices involved in land-grabbing do not run directly through the state at all. 
These complex entanglements of ideas and materiality are also evident in the way that the signals of scarcity are also mediated through highly imperfect financial markets. Capital and financial markets especially are oriented towards the estimation of the present value of a future revenue stream (Birchler and Nitzan, 2009). The 2008 financial crisis and the problems of carbon trading (Chan, 2009) have starkly revealed the shortcomings of financial markets in trying to connect investors to new investment frontiers. Nevertheless promoters of investment in farmland, very much like promoters of sub-prime mortgage investments earlier, solicit investments by projecting future trends based on contestable measures of past performance. For instance Savills, a global real estate services provider, has created a Global Farmland Index, which is used to construct a measure for global land prices "showing positive growth in many established and emerging markets” (Savills, 2012, p.4). While Savills acknowledges some measurement problems in the construction of its index, the overall effect is to obscure the severity of these problems and the uncertain political conflicts over land that the future may bring. If US subprime mortgages or carbon derivatives are opaque, agricultural contracts in Sudan, where law is weak or absent, are worse. The contracts in the current wave of land acquisitions primarily promise long-range benefits such as the construction of infrastructure or the generation of employment, in exchange for very cheap or even free rights to the land (usually in the form of long-term leases). Even some advocates of large-scale land acquisitions, such as the World Bank, have found a shocking lack of evidence that these long-run benefits will materialize. There are many examples of land being held for its speculative value (e.g. World Bank, 2009, p. 45), reducing its current use for agriculture by expropriating those currently working the land or by making the land unaffordable to them.

The ideational and material interface is also present in the recent structural upward shift in food prices. Rising world food prices are not a simple reflection of supply and demand but reflect the increasingly complex interplay between actors and ideas across global financial, energy and food markets (Clapp and Helleiner, 2012). Developing countries have for decades been competing in world food markets under declining terms of trade. The current commodities "boom" is widely regarded as an exciting and dynamic conjuncture with perceptions among private and public actors of the untapped opportunity and profitability this affords taking on the status of conventional economic wisdom (Deutsche Bank, 2009). Land, and the potential to overcome the "yield gap" with the incorporation of modern biotechnology, is increasingly viewed as an underexploited asset and driving actors to invest in the sector with a clear herd-like mentality. Yet is critical that sustainability concerns are almost entirely absent in the new enthusiasm for agriculture.

Another complex interaction between ideas and materiality is highlighted by the very prominent place that transparency plays in the World Bank’s influential report (2009, p. vii, 26) on land grabbing:

'a major conclusion of the report is that access to a basic set of good information is essential for all stakeholders...As long as property rights to land and, where necessary water, are well-defined and a proper regulatory framework to prevent externalities is in place, productivity- and welfare-enhancing transactions can occur without the need for active intervention by the state."

This prioritization of information provision matches the interests of the writers of the report, who are advocating more of what they themselves do. Transparency has been promoted as a solution to a wide range of governance problems, including in finance (Best, 2005) and the extractive sector (Haufler, 2010). However this reliance on transparency is seriously problematic in two overlapping ways. First, it advocates reliance on a process of information dissemination which obscures the deficiencies of that process itself. These deficiencies include especially the 
influence of power differentials on what information is produced, who can disseminate it, and who can access it. Second, it obscures the significance of material and political practices that operate independently of the information dissemination process. The idea of transparency can operate like ideology in obscuring, legitimizing, and therefore helping to produce exploitative material practices associated with land grabbing.

More specifically, the emphasis on transparency obscures the massive asymmetries in "voluntary" contracting between large investors, such as sovereign wealth funds, and those at risk in the land acquisition, such as someone whose family has engaged in pastoral agriculture for generations without formal legal title to the land or any resources to produce or defend such a title (Cotula, 2012). There are also gender dimensions to these asymmetries with many land deals failing to take the needs and interests, and differentiated consequences of men and women (Behrman, Meinzen-Dick and Quisumbing, 2012). Case studies from Sub-Saharan Africa (Chu, 2011) and Indonesia (Julia and White, 2012) show that were land titles are more often held by men than women, even though women make up the disproportionate proportion of the agricultural work force, women continue to face significant institutional, legal, and social barriers to equal access to land rights. As Borras and Franco (2010, p. 519) emphasize, transparency is not the same as accountability; transparency does not ensure transactions are accountable to the interest of the rural power.

The World Bank report itself provides many examples of outright failures to consult, proforma consultations, or consultations with some stakeholders and not others - particularly with men and not the women who are most affected (World Bank, 2009, pp. 49-50). Disclosure policies and the framework of prior and informed consent - as compared to more stringent regulations - can shift risk towards those who are presently using the land, unfairly legitimizing and empowering those with resources who wish to acquire land, and leaving existing exploitative market practices intact (Gupta, 2010, pp. 34-35).

Despite these problems, the complex interaction of ideas and materiality does not always work relentlessly against vulnerable actors. Most present land acquisitions are leases, which legally could be terminated if the investor does not follow through on commitments - or even if domestic politics changes. Local protests and the transnational support mechanisms for these create intangible but materially significant investment risks that provide incentives for foreign investors to address the concerns of critics.

\section{The Complexity of Transnational Governance}

In this section we will see that the complexity of the transnational governance institutions that are addressing land grabbing matches the complexity that we discussed in the previous two sections. As noted in our earlier theoretical discussion, this complexity, which trumps the shifting balances of power among states, is evident along three axes: by issue area; by the varying mix of public and private elements; and by the mix of local and global elements. We also discuss here the autonomy of new regulatory instruments for land grabbing and the interaction among them and with other governance instruments across scales and issue areas.

We start the discussion by examining the two recent transnational instruments that have been advanced as new institutions for regulating land grabbing: the Principles for Responsible Agricultural Investment that Respects, Livelihoods, and Resources (PRAI) and the Voluntary Guidelines on the Responsible Governance of Tenure of Land, Fisheries and Forests in the Context of National Food Security (hereafter "Voluntary Guidelines"). Complexity is evident in 
the differences in the issue areas that they express: the first is more concerned with investment, and the second with land tenure. Each instrument is embedded in distinct principles, norms, rules, cognitive frames and discourses. The land grabbing phenomena is pulling these two regimes, including their rules and constituent actors, into a closer orbit. This process is increasing the diversity and density of actors engaged in global rule-making over land. These include state and non-state actors that have access to and participate in these and related regimes, but which may have not previously operated in the same governance spaces, such as the International Planning Committee for Food Sovereignty and the World Bank are now doing at the FAO’s Committee on World Food Security (CFS) (McKeon, 2013, this volume).

Situating these instruments within an issue area permits us to contextualize the actors, interests and ideas in these new global rule-making projects. Recall that it was the G8, not investors, that tasked multilateral organizations to develop an international framework for responsible investment in agriculture at its 2009 Summit (G8, 2009, p.3; Vidal, 2009). Whereas PRAI is often referred to as a form of private governance (i.e., it is intended to provide socially responsible investment by private actors), its development has been primarily an exercise of consultation and deliberation among experts from international institutions. In fact, multistakeholder consultation processes will only start to shape a new framework for responsible agriculture investment significantly after several years of work by international public officials.

The World Bank has demonstrated significant intellectual and organizational leadership in the PRAI project. PRAI has been presented by its creators to the outside world as a set of evidenced-based codes and best practices assembled to guide and inform decision-making by investors (and host states when courting investment in agriculture). The primary objective of the PRAI is clear: it is to encourage and intensify private investment in agriculture and to enhance the commercial viability of such investments by reducing investor risk. (PRAI, 2010, pp. 2-14). It is very much part of the regulate to facilitate camp in the land grabbing governance debate (see Borras, Franco and Wang, 2013, this volume). Very importantly, PRAI lacks a normative basis for weighing the different type of risks and emphasizes a procedural approach where transparency and disclosure are pre-eminent.

The second initiative, the Voluntary Guidelines, traces it origins to the 2006 UN International Conference on Agrarian Reform and Rural Development (ICARRD) and longerterm concerns about land tenure and land reform in developing countries (McKeon, 2013, this volume; Seufert, 2013, this volume). Multi-actor negotiations, involving states and representatives from international institutions, global civil society and the private sector, began in April 2011 and completed recently in May 2012. This is an important difference to PRAI because global civil society participation has been significant, and has elevated the perceived legitimacy of the Voluntary Guidelines. The Voluntary Guidelines, initially endorsed by the FAO's CFS, have been further endorsed and legitimized by the G20 Heads of State, who 'encouraged' its implementation (G20, 2012). Work on the Voluntary Guidelines has shifted towards devising a plan for implementation, including mechanisms to monitor and evaluate the guidelines, seeking financial support from donors and other multilateral institutions, and assisting individual developing countries to codify the Voluntary Guidelines in domestic law and practices. In contrast to the investment focus of PRAI, the primary objective of the Voluntary Guidelines is to enhance the tenure security of landholders and users, and increase access to land and productive resources by poor rural households. In emphasizing its concern with "the benefit of all, with an emphasis on vulnerable and marginalized people" it has a more explicit normative emphasis than PRAI (FAO, 2010, p. 5). The guidelines resonate with alternative visions of the 
relationship between the economy, people and the Earth (FAO, 2010, p.13). Unlike PRAI's unquestioned approach of integrating rural farmers with global finance and agrifood chains ${ }^{6}$, the guidelines seek to maintain the viability of smallholder production and autonomy of rural and indigenous communities. Global civil society groups and transnational peasant movements continue to support the Voluntary Guidelines as an important bulwark against land grabbing (Global Witness 2010; Civil Society Mechanism, 2011, p. 4). As such, the Voluntary Guidelines were clearly part of a significant norm-generating exercise in transnational governance. The diffusion of these norms to the ground-level is the present challenge.

A new dimension of complexity has to do with increasing interaction between PRAI and the Voluntary Guidelines. As discussed above, each instrument developed in unique way, addresses a different issue and has been supported by a different set of actors. Yet increasingly these instruments are not independent of one another. First, the final text of the negotiated Voluntary Guidelines includes provisions on "responsible investment" and more direct reference to large-scale land acquisitions (FAO, 2011, pp. 23-25). Second, there is now a concerted effort to bridge the PRAI and Voluntary Guidelines by creating a new set of principles. These principles, while taking into account the work to date on PRAI, would be more 'extensive'. They would involve multi-stakeholder negotiation under the auspices of the CFS and ensure that they are consistent and complementary with the Voluntary Guidelines (FAO, 2011) Such convergence is highly contentious, because global civil society actors see PRAI as a threat to protecting land rights of the poor and as a guise for a long-term corporate takeover of rural people's farmlands (GCAR, 2010). However, this regime/forum-shifting (Hefler, 2004) of the negotiation of the principles to the CFS away from the G8 supported inter-agency process may be regarded as a step towards enhancing inclusiveness, participation and legitimacy, and it signals some partial success in the orchestration strategy by global civil society. The CFS certainly lends a gloss of legitimacy to the idea of PRAI that was previously lacking. This also will put greater pressure on global civil society to achieve its ends because it will likely necessitate the greater inclusion of private actors. Research has shown that private actors use their technical expertise very effectively in the creation of new transnational governance (Haufler, Cutler and Porter, 1999) and that this, in turn, intensifies asymmetries in the negotiation process that favours actor with higher levels of expertise and material resources (Quack, 2010).

Global complexity is also intensified by the overlap between the principles and guidelines discussed so far with a broader set of international and regional regulatory frameworks, codes, and informal rules at the international, national and sub-national levels. The Voluntary Guidelines refer and build upon a variety of other codes, rules, and agreements, including ICARRD, international human rights law (e.g., right to food, land, and of indigenous peoples), and regional initiatives such the African Union's recent land policy framework (AU, 2010). With respect to global investment rules already in place, these include the OECD's Policy Framework for Investment (PFI), OECD Guidelines for Multinational Enterprises (the MNE Guidelines), and the OECD Risk Awareness Tool for MNEs in Weak Governance Zones (WGZ Tool) to name a few (OECD 2010). The principles explicitly build on existing codes of conduct and best practices. However, actors negotiating the principles at the CFS are not necessarily linked to the existing transnational public and private networks that monitor and implement these and other finance and investment related governance instruments. It is important to note that the latter instruments are not fixed but are themselves quite fluid. Any future 'principles" are unlikely to be wholly determined by the actors formally involved in the negotiation at the CFS on the specifics. They will also be indirectly influenced by events and actors at other institutions, such 
as the OECD and other mechanisms of financial governance. Consequently, this situation increases the complexity of the task facing the CFS: to establish meaningful principles that are seen as legitimate by investors (which are the primary target of such rules), that can build upon existing monitoring systems for investment useful for naming and shaming purposes, and that can foster the 'ratcheting up' of standards across the investment regime. This is a tall order but one that may be less onerous if transnational advocacy groups concerned with land grabbing can establish coalitions with other global civil society, institutional actors and sympathetic policy elites already active on global investment issues.

The complexity of the public-private dimension also plays out in the Voluntary Guidelines and PRAI. Take the Voluntary Guidelines, which are focused on land tenure that is foremost a national public responsibility, but whose negotiation involved significant input from global civil society (and to a much lesser the private sector). The PRAI on the other hand, were formulated primarily by supra-national public authorities, but that only have meaning if incorporated by investors. PRAI's vision involves a more prominent role for the private sector with private standards and other benchmarks as the building blocs of effective governance. Private governance is also evident in other institutions that complement the above two instruments. These include certification schemes such as the Roundtable on Sustainable Palm Oil or the Roundtable on Sustainable Biofuels (World Bank, 2009, pp. 96-97; see also Fortin and Richardson, 2013, this volume), and the UN Global Compact.

Indeed, the blurring of the public-private axis is likely to become more pronounced in the implementation stage for both these new instruments. Non-state actors such as global civil society organizations or private hedge funds also play an important role in influencing the two initiatives as they continue to develop, although this influence remains contested. Certainly some states continue to strongly assert their sovereignty. As a government official in the Office du Niger put it in response to criticisms of land grabbing "We are responsible for developing Mali. If the civil society does not agree with the way we are doing it, they can go jump in a lake" (MacFarquhar, 2010). Yet as Ruggie (2008) and others have argued, simple state authority is increasingly insufficient to legitimize and enable the operations of foreign investors in host countries - there is a social license to operate, the terms of which are heavily shaped by local and transnational civil society.

The interaction between public and private is also evident in the micro-level practices of the private contracts between small farmers and larger firms that may rent them their land, purchase their crops, and provide inputs or marketing services. These are heavily influenced by the existing capacities of the actors involved, the legal regime within which they are operating, and the physical characteristics of the plants and machinery involved (World Bank, 2009). A similar point can be made about gender relations within the household, which govern the differing allocations of individuals' engagements with the land, the modes of mobility that shape their daily and seasonal movement across the land, and their capacities to engage with the legal regime that constitutes property rights and contracts, blurring the boundary between a "private" household space and a larger public sphere,

These micro-level factors also highlight the global/local axis of complexity. Countries vary in land ownership and property rights transfer rules. Present land ownership patterns are often a result of specific historical patterns and the internal political dynamics of countries. For instance, ironically Brazil's anachronistic constitutional rules may help it control the amount of land that can be purchased by foreign companies. In many poor countries of South such capacity is weaker, making them vulnerable to asymmetrical power relations. 
Struggles between globality and localness are evident at all scales. PRAI's reference to global principles of environmental sustainability (PRAI, 2011, p. 18) only has meaning in its implementation at the most local, micro-level, including, for instance, the interaction between the roots of a plant and the nutrients of the soil, which can either be sustainable, or a form of "soilmining" where the foreign investor takes the nutrients without compensation, destroying the land. Virtual water exports where scarce water is exploited in developing countries by exporting water-intensive crops is similar (Barlow, 2007). Determining which is occurring and acting on it requires an engagement of science with that particular crop, land and farmer. The enforcement of the transnational governance instrument therefore requires a chain of capacities, rules and practices that interactively link the transnational principles with the farmer and the local ecosystem. National institutions are important in this chain, but only one part of it, and not necessarily the most decisive one.

Land grabbing is also linking states and rural peoples situated at the local to new global commercial commodity chains, including the complex mix of investment, trade, and private rules that undergird these exchanges. As recent acquisitions suggest, there is a strong economic incentive to outsource parts of the food, feed and biofuel production process. This has to do with shifting the burden of costs of production to poor developing countries were wages are cheaper, land is "underutilized" (often claimed falsely by governments and investors to be so), and where environmental governance and enforcement is weak. Much of this facilitated by international, bilateral and regional investment and trade agreements as well as economic cooperation partnerships.

To sum up, new regulation of land is linked across multiple governance regimes at the transnational, regional, national, and local levels. The governance of land grabbing certainly cannot be reduced to PRAI or the Voluntary Guidelines. Conflicts reveal characteristics of chessboard politics that were discussed earlier. Non-state actors such as multilateral institutions and global civil society are also maneuvering in this political chessboard. PRAI and the Voluntary Guidelines rest upon multiple clusters of governance practices, all of which operate under of the authority of diverse and distant configurations of state and non-state actors. They go far beyond the simpler shift in the balance of power signified by the replacement of the G8 by the G20, or the decline in US dominance. While newly powerful states such as China and the Gulf states may be less attentive to these complex set of transnational institutions, they too must work through them to some degree, especially in needing to interact with host states and other local actors that in turn are connected in complex was to the transnational institutions.

\section{Strategies for Protecting the Vulnerable}

Our fourth proposition was that that smaller and poorer actors will be most successful working through the types of complexity we have discussed above and enrolling transnational actors and networks in efforts to change governance rather than trying to avoid or reverse complexity by focusing more exclusively on solutions at the local level or at the formal intergovernmental level (for instance through treaties). There is already some support in the discussion above for this: the sheer complexity of the challenges makes it impossible for any one actor to manage them. No single formal intergovernmental organization can manage this complexity either. Treaties are simply too slow.

There are three main additional reasons why local responses alone will not work. First, by avoiding transnational engagements important economic and social benefits may be lost. 
Chronic poverty, food insecurity, limited access to credit and technology, ecological constraints and political disfranchisement are serious challenges facing many of the world's rural poor. Economic globalization increases the pressures on these populations as demand for natural resources and agricultural output intensifies, intensifying what Sassen (2010: Sassen, 2013, this volume) refers to as the 'savage sorting of losers'. At the same time, it is important to keep in mind that urbanization and transitioning of the rural poor from a global majority to minority may in the long-term further diminish their political voice. These are very real challenges for the formulation of socially just land governance. These larger forces suggest the importance for rural people and their advocates to develop bottom-up 'best practices', that reflect the needs, knowledge, and aspirations of existing land users, but that also can engage and enroll other powerful transnational actors and steer projects towards relatively more beneficial forms that respect existing land arrangements.

Second, transnational developments will continue to impinge on the local, even if strong local prohibitions on land grabbing were in place. This includes climate change and the destruction of water sources far from the local farm. Third, local power relations may be even more unfavourable to poor users of land than transnational ones. This includes gender relations in the family, local authorities that do not listen to their constituents, and national states that serve the interests of urban skilled elites. For instance in northern Argentina, local states officials, landowning elites, and foreign investors have clear-cut over 60,000 hectares for soybean production destined for China. This has occurred in an area where rural communities have earned their livelihoods by small-scale sheep herding on customary used land. Large-scale land deals between the Ethiopian state and foreign investors are producing high tech mega-farms, including the acquisition by the Indian firm Karuturi Global of 300,000 hectares. Media reports local workers earn income below the extreme poverty threshold and, more recently, allegations of forced evictions, murder and rape of villagers have surfaced concerning this deal (Bloomberg News, 2009). The World Bank's own research suggests that much of the land grabbing is being carried out by domestic investors, often with privileged access to the state (Deininger et al, 2011). Even though this claim is not fully supported by all studies, it provides a reminder that the shocking lack of transparency in the documentation and accountability mechanisms for investment is not only due to lack of state capacity in host countries, but also officials' desires to be unaccountable.

There are significant opportunities for the poorest farmers to obtain greater protection if the various elements in the transnational arrangements that might be helpful to them are successfully orchestrated. The efforts by global civil society and peasant organizations to support the Voluntary Guidelines and subsume PRAI is one example. Firms reliant on financial and product markets in democracies can be held accountable through a variety of mechanisms, including public regulation, private litigation, reputational damage to their brand, and organized protests. International campaigns and consumer boycotts against blood diamonds, use of sweatshop labour, or cooperation with authoritarian regimes have shifted private actors' perceptions of the importance of responsible behaviour to safeguard reputations and profits. New scientific studies have challenged the purported benefits of biofuels. The fragility and interdependence of the financial system amplifies the risks that investors face in engaging in land grabbing and make them more vulnerable to transnational pressures.

These varied types of responses to the problem of land grabbing have less impact on authoritarian countries, but those countries too have reputational costs that they must consider. For instance in 2013 the Gulf states must act with great care in addressing their citizens' 
demands lest they lose vital support from the US. Even China consented to the rapid referral of the Libyan case to the International Criminal Court, indicating its sensitivity to certain international responses to problems of local violence. In conflicts with the US over exchange rates and other matters vital to China, its human rights reputation, at home and abroad, plays a role in the alliances with the US and others that it can sustain, or even its access to foreign investment opportunities in countries like Canada. Much Chinese investment is through sovereign wealth funds that are operating sufficiently on market principles so that losses from disruptions or reputational damage to the value of the agricultural assets that they hold will be unwelcome.

\section{Conclusion}

Our first three propositions argued that the land-grab illustrates three key changes in the global political economy: changing balance of power and decreasing relevance of framing global relations around either East-West or North-South axes; the direct interaction between ideas and material systemic threats; and the complexity of transnational governance. Our fourth proposition argued that these complex transnational institutions can be helpful for protecting the poorest users of the land. We address these in turn.

First, it is clear that the balance of power has changed. The case of land grabbing does not correspond to earlier cases of North-South conflicts dominated by the European colonial powers or the US. Southern states are major players, as investors, in protecting or abusing their own populations, and in negotiating strong or weak international rules. This introduces more complex dynamics into the transnational political process: Southern states are not "victims" seeking to rebuff the North. Rather, human beings in certain parts of the South are being victimized by a plurality of actors: by states and investors from the South and North but also by local elites. Traditional concepts of South-South solidarity or other traditional forms of interstate political conflict are therefore less relevant to understanding the type of global politics of land grabbing.

Second, the global character of the interaction between ideas and material systemic threats to the Earth and its life-forms is evident in land grabbing. Much of the transnational politics associated with land grabbing can obscure and complicate the broader ecological clash that is at play. This is in part because the two key transnational governance instruments have been developed under the guidance of the G8/G20, a club of powerful states, and the FAO, a food and agriculture policy institution with universal memberships and with a long history of deep engagement with non-state actors, and a concern with growing production. The process has not engaged the climate change regime, which in any case is a relatively new and weak regime. We, like others, view the land grab as part of a wider transformation of the relationship between people and the Earth as much as it is about organizing economies and polities. Agriculture is a major source of greenhouse gas emissions and ecosystem degradation, and also the solution to the current risk that the planet cannot support its human population. Since the vulnerable are the most susceptible yet also the least resourced to respond to the destruction of ecosystems and climate change risks, and since agriculture is asked to sustain the life of the world's population that does not live on the land, the environmental/ecological aspects of governance will be critical going forward. The interactions of scientific knowledge and ideas about the environment with material practices, many of which do not directly involve states, will be important in this. We recognize this aspect will be highly contested by actors; this is already evident in current policy 
debates on agroecology, smart agriculture and ecosystem services as approaches to address the ecological crisis, most notably in the case of green grabs.

Third, it is clear that the interaction of land grabbing with the complexity of transnational governance highlights the significance of each of these for the other. This complexity is evident in the way that the land grab involves new relations between food, fuel, feed and finance that expose communities of persons, which have historically been the most exploited and least able to benefit from the process of wealth generation in the global economy, to ever greater systemic and personal risks. This includes risk to their material wellbeing (i.e., livelihoods by loss of land) but also the security of persons when rural people are faced with forced evictions and violence. In the context of a global economy mediated by the belief in price signals, mechanisms are required to the shift the burden of risk more squarely onto the shoulders of investors, who presently often reap most of the rewards, and who are better capitalized to absorb such risks compared to the rural poor.

Fourth, the complexity of the problem requires complex solutions. Local, national or transnational solutions alone cannot be effective. Nor can purely public or purely private solutions, nor solutions that focus on one issue such as efficiency or investor protection at the expense of the human right to food or the protection of the Earth's ecosystems. Thus all three axes of complexity that we have identified are important. In seeking to defend the rights of poor people threatened by land grabbing it is helpful to work with, expand, strengthen, and alter complex transnational linkages, rather than to try to reduce or cut them. No single governance initiative by itself can be effective. Notions such as chessboard politics, enrolment, and the highlighting of linkages of land regulation to relatively autonomous and distant governance and knowledge practices and flows of power are useful in conceptualizing strategic responses to this complexity.

\section{Acknowledgements}

We thank two anonymous reviewers and Claire Cutler for their comments. An earlier version of this paper was presented at the 2011 International Studies Association annual conference in Montréal, Canada.

\section{References}

Abbott, K. \& Snidal, D. (2009) Strengthening international regulation through transnational new governance: Overcoming the orchestration deficit, Vanderbilt Journal of Transnational Law, 42, pp. 501-578.

African Union (AU) (2010) Land Policy in Africa: A Framework to Strengthen Land Rights, Enhance Productivity and Secure Livelihoods (Addis Ababa: AUC-ECA-AfDB).

Akram-Lodhi, H. (2008) (Re)imagining agrarian relations? The World Development Report 2008: Agriculture for Development, Development and Change, 39(6), pp. 1145-116.

Alden Wily, L. (2012) Looking back to see forward: the legal niceties of land theft in land rushes, Journal of Peasant Studies, 39(3-4), pp. 751-775. 
Alter, K. \& Meunier, S. (2009) The politics of international regime complexity, Perspectives on Politics, 7(1), pp. 13-24.

Anseeuw, W., Wily, L.A., Cotula, L., \& Taylor, M. (2011) Land Rights and the Rush for Land: Findings of the Global Commercial Pressures on Land Research Project (Rome: International land Coalition).

Aradau, C. \& Van Munster, R. (2007) Governing terrorism through risk: Taking precautions, (un)knowing the future, European Journal of International Relations, 13(1), pp. 89-115.

Axelrod, M. (2011) Savings clauses and the 'Chilling Effect': Regime interplay as constraints on international governance/law, in Oberthür, S. \& Stokke, O.S. eds. Managing Institutional Complexity: Regime Interplay and Global Environmental Change, (Cambridge: MIT Press), pp. 87-114.

Ayers, A. J.(2012) Beyond myths, lies and stereotypes: The political economy of a 'New Scramble for Africa', New Political Economy, available as iFirst.

Barlow, M. (2007) Blue Covenant: The Global Water Crisis and the Coming Battle for the Right to Water (Toronto: McLelland \& Stewart).

Barros-Platiau, A.F. (2010) Quando países emergentes reformam a governança global das mudanças climáticas: o Brasil sob Lula, Revista Brasileira de Política Internacional, 53, pp. 73-90.

Behrman, J., Meinzen-Dick, R. \& Quisumbing, A. (2012) The gender implications of large-scale land deals, Journal of Peasant Studies, 39(1), pp. 49-79.

Best, J. (2005) The Limits of Transparency: Ambiguity and the History of International Finance (Ithaca: Cornell University Press).

Biermann, F., Pattberg, P., van Asselt, H. \& Zelli, F. (2009) The fragmentation of global governance architectures: A framework for analysis, Global Environmental Politics, 9(4), pp. 14-40.

Bloomberg News (2009) Ethiopian farms lure investor funds as workers live in poverty, 29 December. Available at: http://www.bloomberg.com/apps/news?pid=newsarchive\&sid=aeuJT_pSE68c

Borras, S.M., Franco, J.C. \& Wang, C. (2013) The challenge of governing land grabs: Changing food regime and competing political tendencies', Globalizations, 10(1).

Borras, S,M., Franco, J.C., Gomez, S., Kay, C. \& Spoor, M (2012) Land grabbing in Latin America and the Caribbean, Journal of Peasant Studies, 39(3-4), pp. 845-872. 
Borras, S.M \& Franco, J. (2010) From threat to opportunity? Problems with the idea of a 'Code of Conduct' for land grabbing, Yale Human Rights \& Development Law Journal, 13(1), pp. 507523.

Borras, S.M., McMichael, P., \& Scoones, I. (2010) The politics of biofuels, land and agrarian change: Editors' introduction, Journal of Peasant Studies, 37(4), pp. 575-592.

Borras, S.M., Hall, R., Scoones, I., White, B. \& Wolford, W. (forthcoming). Governing global land deals: The role of the state in the rush for land, Development \& Change.

Bowles, P. \& Wang, B. The rocky road ahead: China, the US and the future of the dollar, Review of International Political Economy, 15(3), pp. 335-353.

Braithwaite, J. \& Drahos, P. (2000) Global Business Regulation (Cambridge: Cambridge University Press).

Bringezu, S., O’Brien, M.O. \& Schütz, H. (2012) Beyond biofuels: Assessing global land use for domestic consumption of biomass: A conceptual and empirical contribution to sustainable management of global resources, Land Use Policy, 29(1), pp. 224-232.

Busch, L. \& Bain, C. (2009) New! Improved? The transformation of the global agrifood system, Rural Sociology, 69(3): pp. 321-346.

Callon, M. (1986) Some elements of a Sociology of Translation: Domestication of the Scallops and the Fisherman of St. Brieuc Bay. In J. Law, ed. Power, Action and Belief: A New Sociology of Knowledge? 196-233, London: Routledge and Kegan Paul.

Cashore, B. (2003) Legitimacy and the privatization of environmental governance: How nonstate market-rriven (NSMD) governance systems gain rule-making authority, Governance, 15(4), pp. 503-529.

Chan, M. (2009) Subprime Carbon? Re-thinking the world's largest new derivative market (Washington, DC: Friends of the Earth).

Chu, J (2011) Gender and 'land grabbing' in Sub-Saharan Africa: Women's land rights and customary land tenure, Development, 54(1), pp. 35-39.

Civil Society Mechanism (CSM) (2011) CSO Consolidated Comments on Zero Draft, 10 April. Accessed 15 February 2012. Available at: http://cso4cfs.files.wordpress.com/2010/11/csocomments-zero-draft-10-05-11-2.pdf

Clapp, J. \& Helleiner, E. (2012) Troubled futures? The global food crisis and the politics of agricultural derivatives regulation, Review of International Political Economy, 19(2), pp. 181207. 
Clapp, J. \& Fuchs, D. (eds) (2009) Corporate Power in Global Agrifood Governance

(Cambridge, MA: MIT University Press).

Comprehensive African Agriculture Development Program (CAADP) (2010) Renewing the African Commitment to Agriculture (Nairobi: African Union).

Conca, K. (2000) The WTO and the undermining of global environmental governance, Review of International Political Economy, 7(3), pp.484-494.

Cotula, L. (2012) Human Rights, Natural Resource and Investment Law in a Globalized World: Shades of Grey in the Shadow of the Lawi (London: Routledge).

Cotula, L. (2011) Land deals in Africa: What is in the contracts? (London: International Institute for Environment and Development).

Cotula, L., Vermeulen, S., Leonard, R., \& Keeley, J. (2009) Land Grab or Development Opportunity? Agricultural Investment and International Land Feals in Africa. London: International Institute for Environment and Development).

Cutler, A. C., Haufler, V., \& Porter, T. (1999). Private Authority and International Affairs (Binghamton : SUNY Press).

Dauvergne, P., \& Neville, K.J. (2010) Forests, food, and fuel in the tropics: the uneven social and ecological consequences of the emerging political economy of biofuels, Journal of Peasant Studies, 37(4), pp. 631-660.

Dauvergne, P. \& Farias, D. B. (2012) The rise of Brazil as a global development power, Third World Quarterly, 33(5), pp. 903-917.

de Goede, M. (2006) International Political Economy and Poststructural Politics (Basingstoke: Palgrave).

de Haan, A. (2011) Will China change international development as we know it?, Journal of International Development, 23(7), pp. 881-908.

Deininger, K., and D. Byerlee, with Lindsay, J., Norton, A., Selod, H. \& Stickler, M. (2011) Rising Global Interest in Farmland: Can it Yield Sustainable and Equitable Benefits? (Washington, DC: World Bank)

Deutsche Bank (2009) Investing in Agriculture: Far-Reaching Challenge, Significant Opportunity (London \& New York: Deutsche Bank Group).

Djelic, M.L. \& Sahlin-Andersson, K. (eds) (2007) Transnational Governance: Institutional Dynamics of Regulation (Cambridge: Cambridge University Press).

Dobusch, L. \& Quack, S. (2012) Framing standards, mobilizing users: Copyright versus fair use in transnational regulation, Review of International Political Economy, forthcoming. 
Drezner, D.W. (2009) The power and peril of international regime complexity, Perspectives on Politics, 7(1), pp. 65-70.

Eckerseley, R. (2004) The big chill: The WTO and multilateral environmental agreements, Global Environmental Politics, 4(2), pp. 24-50.

Fairhead, J., Leach, M. \& Scoones, I. (2012) Green grabbing: A new appropriation of nature? Journal of Peasant Studies, 39(2), pp. 237-261.

Fisher, D.R., \& Green, J.F. (2004) Understanding disenfranchisement: Civil society and developing countries' influence and participation in global governance for sustainable development, Global Environmental Politics, 4(3), pp. 65-84.

Food and Agriculture Organization of the United Nations (FAO) (2011) Voluntary Guidelines for Responsible Governance Voluntary of Land and Natural Resources: Zero Draft Final (Rome: FAO).

FAO (2010) Voluntary Guidelines for Responsible Governance Voluntary of Land and Natural Resources: Zero Draft (Rome: FAO).

Financial Times, The (2010) Business and Food Sustainability Special Report, 27 January.

Friedmann, H. (1992) Distance and durability: Shaky foundations of the world food economy, Third World Quarterly, 13(2), pp. 371-383.

Foley, J., DeFries, R. Asner, G.A., Barford, C., Bonan, G., Carpenter, S.R., Chapin, F.S., Coe, M.T., Daily, G.C., Gibbs, H.K., Helkowski, J.H., Holloway, T., Howard, T.A., Kucharik, C.J., Monfreda, C., Patz, J.A., Prentice, I.C., Ramankutty, N. \& Snyder, P.K. (2005) Global Consequences of Land Use, Science, 309(5734), pp. 570-574.

Fortin, E. \& Richardson, B. (2013) Certification schemes and the governance of land: Enforcing standards or enabling scrutiny? Globalizations, 10(1).

Global Campaign for Agrarian Reform (CGAR) (2010). Why We Oppose the Principles for Responsible Agricultural Investment. Available at:

http:/www.fian.org/resources/documents/others/why-we-oppose-the-principles-for-responsibleagricultural-investment (accessed March 15, 2012)

GRAIN (2011) Pension funds: key players in the global farmland grab, available at: http://www.grain.org/article/entries/4287-pension-funds-key-players-in-the-global-farmlandgrab.pdf.

GRAIN (2012) Pension funds table as of June 2012, available at: http://www.grain.org/attachments/2520/download. 
Group of Twenty (G20) (2012) G20 Leaders Declaration, available at:

http://g20.org/images/stories/docs/g20/conclu/G20_Leaders_Declaration_2012_1.pdf.

Gupta, A. (2010) Transparency as contested political terrain: who knows what about the global GMO trade and why does it matter? Global Environmental Politics, 10(3), pp. 32-52.

Haas, P. M. (1989) Do regimes matter? Epistemic communities and Mediterranean pollution control, International Organization, 43(3), pp. 377-403.

Harvey, M. \& Pilgrim, S. (2011) The new competition for land: Food, energy, and climate change, Food Policy, 36(Supplement 1), pp. S40-S51.

Haufler, V. (2010) Disclosure as governance: The Extractive Industries Transparency Initiative and resource management in the developing world, Global Environmental Politics, 10(3), pp. 5373.

Hawkins, D.G., Lake, D., Nielson, D.L., \& Tierney, M.J. (2006) Delegation under anarchy: States, international organizations, and principle-agent theory, in Hawkins, D.G., Lake, D., Nielson, D.L., \& Tierney, M.J. (eds), Delegation and Agency in International Organizations (Cambridge: Cambridge University Press), pp. 3-38.

Helfer, L. R. (2004) Regime shifting: the TRIPS agreement and new dynamics of international intellectual property lawmaking, Yale Journal of International Law, 29(1), pp. 1-83.

High Level Panel of Experts (HLPE) (2011) Land Tenure and International Investments in Agriculture: A Report by the High Level Panel of Experts on Food Security and Nutrition of the Committee on World Food Security (Rome: FAO).

Hobsbawm, E.J. (1987) The Age of Empire, 1875-1914 (New York: Pantheon Books).

Hochstetler, K. \&Viola, E. (2012) Brazil and the politics of climate change: beyond the global commons, Environmental Politics, 21(5), pp. 753-771.

Hooge, L. \& Marks, G. (2003) Unraveling the central State, but how? Types of multi-level governance, American Political Science Review, 97(2), pp. 233-43.

Hopewell, K. (2012) New protagonists in global economic governance: The rise of Brazilian business at the WTO, New Political Economy, forthcoming.

Hunsberger, C. (2010) The politics of Jatropha-based biofuels in Kenya: convergence and divergence among NGOs, donors, government officials and farmers, Journal of Peasant Studies, 37(4), pp. 939-962.

Immerman, R.H. (1983) The CIA in Guatemala: The Foreign Policy of Intervention (Austin: University of Texas Press). 
Jessop, B. \& Sum, N.L. (2006) Beyond the Regulation Approach: Putting Capitalist Economies in their Place (Cheltenham: Edward Elgar).

Jessop, B. (2004) Multi-level governance and multi-level metagovernance” in Bache, I. \& Flinders, M. (eds), Multi-Level Governance (Oxford: Oxford University Press), pp. 49-74.

Johnson, T. \& Urpelainen, J. (2012) A strategic theory of regime integration and separation, International Organization 66(4), pp. 645-677.

Julia \& White, B. (2012) Gendered experiences of dispossession: oil palm expansion in a Dayak Hibun community in West Kalimantan, Journal of Peasant Studies, 39(3-4), pp. 995-1016.

Keck, M.E. \& Sikkink, K. (1998) Activists Beyond Borders (Ithaca, New York: Cornell University Press).

Lake, D.A., (1993), Leadership, hegemony, and the international economy: Naked emperor or tattered monarch with otential?, International Studies Quarterly, 37(4), pp. 459-89.

Lambin, E.F., \& Meyfroidt, P (2011) Global land use change, economic globalization, and the looming land scarcity, Proceedings of the National Academy of Sciences, 108(9), pp. 3465-3472.

Lesage, D., Van de Graaf, T. \& Westphal, K (2010) Global Energy Governance in a Multipolar World (Surrey: Ashgate).

Levi-Faur, D. (2005) The global diffusion of regulatory capitalism, The Annals of the American Academy of Political and Social Science, 598, pp. 12-32.

MacFarquhar, N. (2010) African farmers displaced as investors move in, New York Times 21 December.

Margulis, M.E. (2012) Global food security governance: The Committee on World Food Security, Comprehensive Framework for Action and the G8/G20, in Rayfuse, R. \& Weisfelt, N., The Challenge of Food Security: International Policy and Regulatory Frameworks (Cheltenham, UK: Edward Elgar), pp. 231-254.

Margulis, M.E., McKeon, N \& Borras, S.M. (2013) Land grabbing and global governance: A critical introduction, Globalizations, 10(1).

Martinez-Diaz, L. \& Woods, N. (2009) Introduction: Developing countries in a networked global order," in Martinez-Diaz, L. and Woods, N. (eds), Networks of Influence? Developing Countries in a Networked Global Order (Oxford, Oxford University Press), pp. 1-18.

McMichael, P. (2009) A food regime genealogy, Journal of Peasant Studies 36(1), pp. 171-196.

McKeon, N. (2013) “One does not sell the land upon which the people walk": Land grabbing, rural social movements, and global governance, Globalizations, 10(1). 
McMichael, P. (2012) The land grab and corporate food regime restructuring, Journal of Peasant Studies, 39(3\&4), pp. 681-701.

McMichael, P. (2013) Land grabbing as security mercantilism in international relations, Globalizations, 10(1).

Mehta, L. Veldwisch, J.V. \& Franco, J. (2012) Introduction to the Special Issue: Water grabbing? Focus on the (re)appropriation of finite water resources, Water Alternatives, 5(2), pp. 193-207.

Morgan, B. (2006) Turning off the tap: Urban water service delivery and the social construction of global administrative law, European Journal of International Law, 17(1), pp. 215-46. Organization for Economic Cooperation and Development (OECD) (2010) Freedom of Investment Process: Responsible Investment in Agriculture. Note by the Secretariat (Paris: OECD).

Narlikar, A. \& Tussie, D. (2004) The G20 at the Cancun ministerial: Developing countries and their evolving coalitions in the WTO, World Economy, 27(7), pp. 947-966

Narlikar, A. \& Wilkinson, R. (2004) Collapse at the WTO: a Cancun post-mortem, Third World Quarterly, 25(3), pp. 447-460.

Nye, Jr., J.S. (2005) Soft Power: The Means To Success In World Politics (Ney York: Public Affairs).

Oberthür, S. \& Gehring, T. (2006) Institutional interaction in global environmental governance: The case of the Cartagena Protocol and the World Trade Organization, Global Environmental Politics, 6(2), pp. 1-31.

Ong, A. \& Collier, S.J. (2005) Global Assemblages: Technology, Politics and Ethics as Anthropological Problems (Malden: Blackwell).

Oxfam (2012), Land and Power: The growing scandal surrounding the new wave of investments in land, available at: http://www.oxfam.org/sites/www.oxfam.org/files/bp151-land-power-rightsacquisitions-220911-en.pdf.

Quack, S. (2010). Law, expertise and legitimacy in transnational economic governance: an introduction, Socio-Economic Review, 8(1), pp. 3-16.

Perrone, N.M (2013) Restrictions on foreign acquisitions of agricultural land in Argentina and Brazil, Globalizations, 10(1).

Porter, T. (2012) Making serious measures: Numerical indices, peer review, and transnational actor-networks, Journal of International Relations and Development, 15(4), pp. 532-557. 
Principles for Responsible Agricultural Investment that Respects, Livelihoods, and Resources (PRAI) (2010), Extended Version (Washington: World Bank).

Raustiala, K. \& Victor, D. (2004) The regime complex for plant genetic resources, International Organization, 58(2), pp. 277-309.

Ruggie, J.G. (2008) Protect, respect and remedy: A framework for business and human rights, Innovations: Technology, Governance, Globalization, 3(2), pp. 89-212.

Sassen, S. (2013) Land grabs today: Feeding the disassembling of national territory, Globalizations, 10(1).

Sassen, S. (2010) A savage sorting of winners and losers: Contemporary versions of primitive accumulation, Globalizations, 7(1-2), pp. 23-50.

Sassen, S. (2006) Territory, Authority, Rights: From Medieval to Global Assemblages (Princeton: Princeton University Press).

Savills (2012) "Going with the Grain: Why International Farmland is Becoming an Increasingly Sought After Investment,” International Farmland Focus 2012, Savill Research Rural, Available at: http://pdf.euro.savills.co.uk/global-research/international-farmland-focus.pdf.

Sell, S. K., \& Prakash, A. (2004) Using ideas strategically: The contest between business and NGO networks in intellectual property rights, International Studies Quarterly, 48(1), pp.143175.

Seufert, P. (2013) Voluntary Guidelines on the Responsible Governance of Tenure of Land, Fisheries and Forests, Globalizations, 10(1).

Smaller, C., \& Mann, H. L. (2009) A thirst for distant lands: Foreign investment in agricultural land and water (Winnipeg: International Institute for Sustainable Development).

Suárez de Vivero, J.L. \& Rodríguez Mateos, J.C. (2010) Ocean governance in a competitive world: The BRIC countries as emerging maritime powers-building new geopolitical scenarios, Marine Policy, 34(5), pp. 967-978.

Tan-Mullins, M., Mohan, G. \& Power, M. (2010) Redefining 'Aid' in the China-Africa Context, Development and Change, 41(5), pp. 857-881.

Veggeland, F. \& Borgen, S.O. (2005) Negotiating international food atandards: The World Trade Organization's impact on the Codex Alimentarius Commission, Governance, 18(4), pp. 675-708.

Victor, D.G. \& Yueh, L. (2010 The new energy order, Foreign Affairs, 89(1), pp. 61-73. 
Vidal, J. (2009) Fears for the world's poor countries as the rich grab land to grow food, The Guardian, 3 July. Available at: http://www.guardian.co.uk/environment/2009/jul/03/landgrabbing-food-environment

Vihma, V. (2011) India and the global climate governance: Between principles and pragmatism, The Journal of Environment \& Development March, 20(1), pp. 69-94.

Wade, R.H. (2011) Emerging world order?: from multipolarity to multilateralism in the G20, the World Bank, and the IMF, Politics \& Society, 39(3), pp. 347-378.

Wallerstein, I. (1974) The rise and future demise of the world capitalist system: Concepts for comparative analysis, Comparative Studies in Society and History, 16(4), pp. 387-415.

Walz, J. \& Ramachandran, V. (2011) Brave new world: A literature review of emerging donors and the changing nature of foreign assistance, Center for Global Development Working Papers, available at:

http://cgdev.org/files/1425691_file_Walz_Ramachandran_Brave_New_World_FINAL.pdf.

Weaver, J. (2003) The Great Land Rush and the Making of the Modern World, 1650-1900 (Montreal: McGill-Queens University Press).

Wendt. A. (1995) Constructing international politics, International Security, 20(1), pp. 71-81.

White, L. (2010) Understanding Brazil's new drive for Africa, South African Journal of International Affairs, 17(2), pp. 221-242.

Williams, M. (2005) The Third World and global environmental negotiations: Interests, institutions and ideas, Global Environmental Politics, 5(3), pp. 48-69.

Woertz, E. (2013) Gulf states and the governance of agro-investments, Globalizations, 10(1).

Woods, N. (2008) Whose aid? Whose influence? China, emerging donors and the silent revolution in development assistance, International Affairs, 84(6), pp. 1205-1221.

World Bank (2009) Large-Scale Acquisition of Land Rights for Agricultural or Natural Resource-based (Washington: World Bank).

Young, O.R., Chambers, W.B., Kim, J. \& ten Have, C. (2008) Institutional Interplay: Biosafety and Trade (New York: United Nations University Press).

Zoomers, A. (2010) Globalisation and the foreignisation of space: Seven processes driving the current global land grab, Journal of Peasant Studies, 37(2), pp. 429-447.

Zürn, M. (2004) Global governance and legitimacy problems, Government and Opposition, 39(2), pp. 260-287. 
Matias E. Margulis is Assistant Professor of International Studies at the University of Northern British Columbia and a postdoctoral fellow at the Max Planck Institute for the Study of Societies. He is currently writing a book on the global politics of international trade and food security. He is a former Canadian trade policy advisor and has worked on global food security policy at several multilateral organizations.

Tony Porter is Professor of Political Science at McMaster University in Hamilton, Canada. His books include Globalization and Finance (Polity Press, 2005), The Challenges of Global Business Authority: Democratic Renewal, Stalemate, or Decay? (SUNY Press, 2010), coedited with Karsten Ronit, and Transnational Financial Associations and the Governance of Global Finance: Assembling Power and Wealth (Routledge, 2013), coauthored with Heather McKeenEdwards.

\footnotetext{
${ }^{1}$ The relevant literatures are large. See for instance Biermann et al. (2009); Braithwaite and Drahos (2000); Djelic and Sahlin-Andersson (2007); Levi-Faur (2005); Ong and Collier (2005); Sassen (2006); Hooge and Marks (2003); Jessop (2004); Hawkins et al. (2006); Morgan (2006); Raustalia and Victor (2005); Young et al. (2010).

${ }^{2}$ The most extensive development of the opportunities for weak actors to make use of enrolment in global business regulation is provided by Braithwaite and Drahos (2000). An early well-known development of the concept of enrolment in actor-network theory is provided by Callon (1986). For an application of actor-network theory to transnational governance see also Porter (2012).

${ }^{3}$ The current state of scholarship can be found in the pages of Journal of Peasant Studies 39(2); 39(3-4), Development 54(1), Water Alternatives 5(2), Development \& Change (forthcoming) and the Canadian Journal of Development Studies (forthcoming).

${ }^{4}$ We recognize the exact scale of land grabs, and debate about the best suited methods, remain hotly contested However, it is also important to contextualize the politics of measurement as one aspect of the ideational contests at play in the transnational governance of land grabs (see Margulis, Borras and Mckeon, 2013, this volume).

${ }^{5}$ Take for example, Savills, a global real estate service provider, that has developed a Global Farmland Index that tracks farmland values in fourteen key markets. These developments further confirm the creation of a global land market.

${ }^{6}$ This approach is consistent with the World Bank’s new agriculture agenda. See Akram-Lodhi (2008).
} 